\title{
Chapter 9 \\ Channels and Barriers of Cross-Border Online Circulation: Central and Eastern Europe as a Digital Periphery
}

\author{
Petr Szczepanik
}

\subsection{Introduction}

The European Commission's Digital Single Market (DSM) strategy is being presented, among other things, as an answer to the notoriously low levels of cross-border circulation of European audiovisual content, as well as to the threats of cultural and economic domination by the USA. In fact, the DSM is just a continuation of long-term policy concerns with barriers in the EU's audiovisual market and has been proposed in hopes that digital technologies will provide a means for improvement, namely for achieving the "objective of intensified and efficient cross-border online distribution of audiovisual works between Member States" (European Parliament 2012: 69). For example, MEDIA — as the European Commission's program supporting audiovisual industries - introduced a scheme focusing on video on demand (VOD) catalogues with a strong European dimension already in 2007, although without significant impact on actual online circulation (De Vinck and Pauwels 2015: 112-113). More generally, these proposals are also in many ways a continuation of the long-lasting debates reflecting concerns about one-way transnational flows and cultural imperialism that started in the 1970 s with the boom in transnational satellite and cable broadcasting (Iordache et al. 2018). But within the DSM debate, American-based digital services do not stand entirely on the other side of a barricade from EU policymakers. Companies such as Netflix and Amazon can potentially benefit from some elements of the DSM, and they are also seen as key gatekeepers and vehicles for the circulation of European content within and beyond the continent.

The Netherlands EU Presidency Conference "Promoting Cross-Border Circulation of European Audiovisual Content" (March 3 and 4, 2016, Amsterdam) symptomatically started with a lengthy clip from Netflix's UK series The Crown and a keynote delivered by Netflix CEO and co-founder Reed Hastings. Hastings warned

\footnotetext{
P. Szczepanik ( $₫)$

Filozofická fakulta Univerzity Karlovy, nám. Jana Palacha 1/2, 11638 Prague, Czech Republic e-mail: Petr.Szczepanik@ff.cuni.cz
} 
against introducing new content quotas and claimed that Netflix does not present a threat but is rather contributing to national cultures by producing local shows and distributing them globally with multiple subtitles. The key condition for this "new global entertainment world," based on "sharing" national cultures across national borders, to flourish in Europe is, according to Hastings, "a lighter regulatory orientation" and policy based on the country of origin principle that allows for one set of regulatory rules to be applied to a company operating across the whole EU (Hastings 2016). The presumption of the European Commission that global digital services will help European films and television programs circulate between individual Member States' territories more widely and smoothly than cinemas and television seems natural, but there is very little empirical evidence of the actual impact VOD services have or are going to have on European distribution ecosystems.

The only EU-wide data on cross-border online circulation publicly available at the moment come from quantitative studies of VOD catalogues - often limited to transactional video on demand (TVOD) or covering subscription video on demand (SVOD) to a lesser extent than TVOD. Since transnational VOD services publish statistics neither on their actual revenues and consumption, nor on the composition of their catalogues in individual markets (and they sometimes make it hard to identify the nationality of individual titles), researchers need to adopt alternative analytical tools and methods to compile distribution and reception data, some of them resorting to unofficial third parties' databases such as uNoGS (cf. Lobato 2018; Aguiar and Waldfogel 2018). The most useful pan-EU studies so far have been produced by the European Audiovisual Observatory (EAO), although even they still provide only rough approximations due to the lack of data and skewed samples, especially for SVOD. ${ }^{1}$ These reports typically ask about the share of national, EU28, or non-national EU28 (NNE) content in VOD catalogues, sometimes distinguishing between different types of services or between TV series and films. On the most general level, recent studies reflecting on developments in the period between 2016 and 2018 showed that SVOD catalogues are smaller, less diverse in terms of the country of origin, more recent and more TV-dominated and include less EU28 content than TVODs: on average $21 \%$ versus $29 \%$ of EU films and $25 \%$ versus $40 \%$ of EU TV fiction, respectively. There are significant differences between national and transnational services, though. National TVODs and even more so national SVODs are less diverse in terms of the number of producing countries but include a higher share of national and EU28 titles (45 and 48\% for EU28 films and 19 and $20 \%$ for national films, respectively) and a lesser share of US titles than their multi-country competitors (23 and 18\% for EU28 films and 6 and 3\% for national films, respectively). For example, EU28 films comprised $48 \%$ of the catalogue of Czech SVOD Voyo (27\% NNE and $21 \%$ national titles). This means that national services, although more "European," devote a large part of their catalogues' EU28 segments (42\% in TVOD and $41 \%$ in SVOD) to national productions, thus limiting the circulation of NNE content. Significant differences occur not just between various VOD services (national and

\footnotetext{
${ }^{1}$ The following two paragraphs are based on Fontaine (2019a: 26-29, 2019b: 12-14), Grece (2017a: 90, b: 19, 2019).
} 
global, niche and mainstream), but also between the different territorial catalogues of the same transnational service: The share of national content in the transnational services' catalogues is largest in the big film-producing countries (the so-called EU5: the UK, France, Germany, Italy and Spain) and is significantly smaller or close to zero in smaller countries. For example, it was just two films in the Czech Netflix catalogue as of July 2019, out of almost 5000 titles.

These data do not say much about the actual demand and revenues of the online distribution, they do not distinguish between different types of content (beyond national origin, the year of production and film vs. TV), nor do they indicate-most importantly for this chapter-why and how specific titles ended up in a specific VOD catalogue. They demonstrate only a general pattern of cross-border circulation. At the same time, the data have begun (after having been repeatedly updated and methodologically upgraded) hinting at specific regularities in and barriers to the cross-border circulation of EU28 content. The obvious barriers include overproduction (too many EU28 titles released every year if compared to the USA), linguistic and cultural distance, narrow theatrical releases, weak marketing campaigns and territory-byterritory licensing. The emerging regularities indicate that EU28 films travel more widely on TVOD, that TV series cross borders more often on SVOD and that there are persistent differences between the circulations of US and EU28 content. While in 2018 a single EU28 film was available on TVOD in 2.7 EU countries and on SVOD in 2.5 EU countries on average, a US film fared much better across borders, being available in 6 EU countries on TVOD and 4.8 on SVOD. There is also a significant level of concentration: The biggest production countries, especially the UK, are dominating both SVOD and TVOD catalogues' EU28 segments. The UK, France and Germany alone represent $60 \%$ of all EU films in TVOD and SVOD catalogues combined. In the case of smaller EU countries, cultural-geographic clusters (such as the Czech Republic and Slovakia) are the most significant and predictable drivers of cross-border circulation.

This chapter looks beneath the purely quantitative data on cross-border availability by investigating industry practices of online distribution from a peripheral, small-market perspective, using the example of export from the Czech Republic. The key research question is: How have transnational VODs integrated into the local industry ecosystem and to what extent have they changed the circulation trajectories of Czech films and TV series? First, it places online distribution within the local industry ecosystem and reveals the systemic barriers that discourage producers and distributors from strategically focusing on foreign markets. Second, it identifies the key intermediaries and practices of cross-border online distribution, focusing on the approach of global VOD services to distributing small nation content across borders. The chapter concludes with a typology of cross-border online distribution to distinguish different strategies and tactics employed by key players when approaching foreign markets. Thus, it calls for a more nuanced perspective on the position of "digital peripheries" in cross-border cultural networks and flows.

Methodologically, the research behind the chapter draws on the approaches of critical media industry studies, distribution studies, transnational media flow studies and 
the recent critical literature on Netflix. It is based, first, on a set of semi-structured indepth interviews with producers, distributors, broadcasters, aggregators, sales agents and VOD portal operators ${ }^{2}$; second, an analysis of European and national policy documents; and third, on an original catalogue data analysis of the biggest transnational VOD services in four key export territories for Czech films: the USA, Germany, France and Poland. ${ }^{3}$ It focuses on the circulation of Czech content as a case study and compares it with similar post-socialist markets in the region (the other so-called Visegrad countries: Slovakia, Poland and Hungary). The chapter avoids presumptions of one-directional domination; instead, it looks at business models and distribution practices of both global services and local producers and distributors, their mutual interrelationships, and how they are conditioned by national and EU policies. In doing so, it identifies inextricable links between traditional intermediaries and the new ondemand market on the one hand, while also pointing at disruptive, disintermediation practices on the other.

\subsection{VOD in the Small Media Industry Ecosystem}

Existing studies of cross-border circulation show that the small media markets of Central and Eastern Europe (CEE) are by far the least successful exporters of audiovisual content among EU Member States, including small West European countries such as Belgium and Denmark (Higson 2018). The reasons include the typical economic characteristics of small countries' media industries such as the shortage of financial resources, inability to benefit from economies of scale in the home market, a limited pool of internationally established talent and language barriers (see Alaveras and Martens 2018). My own research of producer practices indicates that there are also more specific, cultural-historical factors typical for post-socialist media systems: the lack of strong production houses and low levels of vertical and horizontal integration, the relatively late professionalization and internationalization of independent producers, high levels of dependence on public subsidies and, more generally, enduring structural elements of the former state-socialist media, mainly in the form of the local public service broadcaster (PSB) Česká televize (Czech Television), which is the major local producer and exporter of audiovisual content (Szczepanik 2018).

Although on paper the Czech Republic appears to be the strongest exporter of films among the CEE states, ${ }^{4}$ a closer look reveals that most of its theatrically exported films travel only to neighboring Slovakia, a country of five million with which it

\footnotetext{
${ }^{2}$ The total of 16 interviews were conducted between 2016 and 2019: three producers, five distributors (two of them acting as aggregators, as well), two broadcasting executives, four local VOD operators and two international sales agents.

${ }^{3}$ Catalogue data were compiled from the EU-funded database JustWatch and selectively crosschecked with EAO's new database Lumiere VOD.

${ }^{4}$ According to Holdaway and Scaglioni (2018), the Czech Republic ranked sixth in terms of the total number of films exported in the EU's cinema market between 2007 and 2017 (after the big five countries France, UK, Germany, Italy and Spain).
} 
shares a common state history, and forms a cultural-geographic cluster with the strongest bilateral dependence among all comparable clusters in the EU. ${ }^{5}$ While Slovakia represented $64 \%$ of all Czech film exports in the cinema market, the Czech Republic was even more important export market for Slovakia, taking $71 \%$ of its theatrical film exports in 2015 and 2016 (Grece 2017a: 33). It is not surprising, then, that the average total foreign attendance per theatrical title (when it travelled abroad) was just 18 thousand viewers: far less than the biggest EU exporters such as the UK (627 thousand) and France (140 thousand), but also significantly less than smaller Western European markets such as Denmark (93 thousand) and Belgium (118 thousand) (Holdaway and Scaglioni 2018: 349).

In theatrical distribution, Czech films travel to other countries beyond Slovakia only if they are international co-productions: $95 \%$ of Czech cinematic exports beyond Slovakia between 2013 and 2017 were international co-productions, of which 77\% were minority co-productions (SPI Olsberg 2019). The importance of international partnerships, foreign talent and sales agents (who are generally not interested in fully national Czech films) indicates that in theatrical distribution, there are strong industry regularities determining a film's export potential even before it is finished and before its quality can be judged by buyers and consumers. The typical Czech film that travelled beyond Slovakia (most frequently to Poland, less often to Germany or France, and occasionally to another CEE country) has been an art house international co-production with a French or German sales agent attached; fully national Czech films, on the other hand, have negligible theatrical distribution outside the Czech Republic and Slovakia (SPI Olsberg 2019). The problem is that the production and distribution ecosystem of art house films, as the main export commodity of the CEE screen industries, are not compatible enough with the system of transnational VOD distribution.

The vast majority of online distribution in the local Czech market is still controlled by the established legacy media players: cinema or home video distributors and broadcasters. While the local production sector is extremely disintegrated, consisting of approximately two hundred small companies without any organizational links to other stages in the value chain, the distribution field is quite concentrated with a handful of US studios' local partners (in theatrical and home video distribution) being the dominant players. Home video and cinema distributors are buying and reselling territorial VOD rights, too, but not from the US majors, whose online rights have been traded directly by the studio branches to the transnational and local VOD services. From the domestic market's perspective, online distribution is mostly an undisruptive addition to the well-established licensing practices in theatrical, TV and home video windows. The dominant legacy media players simply expanded their portfolios of rights, but — with the exception of broadcasters—have not invested in their own online portals, largely leaving the field to local telcos and transnational online services (similarly to Poland, as described in Marcin Adamczak's chapter of this book).

\footnotetext{
${ }^{5}$ That is why Slovakia is intentionally excluded from the selection of export territories in this study.
} 
However, as the following sections of the chapter show, the cross-border online distribution of Czech films is changing this arrangement. The local home video distributors still sell a significant proportion of Czech films abroad, but they remain fully dominant only in Slovakia, which tends to be seen as a single market territory together with the Czech Republic. In the case of ambitious art house films and international co-productions, foreign online sales tend to be controlled either by the foreign co-producers and their partners, or by foreign sales agents. Foreign online sales of less internationally appealing, fully national films are relatively decentralized and partly conducted by the small local producers themselves, who are effectively becoming self-distributors by selling their films via TVOD catalogues. Original local productions and exclusive acquisitions of transnational SVODs (HBO and Netflix) are a separate category: Their cross-border circulation is the most selective, but also the most dynamic. A significant exception among the local legacy media players is the Czech PSB “Česká televize," which increasingly focuses on selling the foreign online rights of its vast original production and occasionally acts as a sales agent representing local film producers who have no capacity to handle cross-border distribution themselves. Overall, cross-border online distribution allows Czech films and TV series to reach foreign territories that would have been inaccessible to them in the traditional theatrical or broadcasting windows, especially the USA and Asia.

VOD can either disrupt or enhance the existing business models and practices. In most of the EU so far, VOD represents only a small fraction of the market, but it is growing fast, especially in the small CEE countries (the most rapid SVOD growth of $226 \%$ between 2015 and 2016 was recorded in the Czech Republic, which was also one of the fastest growing markets between 2016 and 2017 with $175 \%$ ), ${ }^{6}$ which were late adopters and still have a low level of penetration. It also seems that Netflix is currently on an especially steep rise in CEE. After subscription numbers stagnated in 2016 and 2017 (after Netflix's "global switch on") due to the weak localization of its CEE catalogues, it has become the largest paid streaming platform in the Czech Republic with approximately 100 thousand subscribers as of May $2019 .^{7}$ Netflix is the second-fastest growing paid SVOD in Poland (Netflix's top country in the CEE region), with an estimated 760 thousand subscribers as of 2018 (which could potentially translate to 1.9 million actual monthly viewers, according to the widely accepted estimate of an average of 2.5 viewers per account). ${ }^{8}$ A business intelligence forecast by Digital TV Research estimated that Netflix will double its 2018 subscription base across Eastern Europe (including Russia) by 2024, reaching 8 million subscribers (two million in Poland alone), and control a 30\% share of the regional market (Thomson 2019a). While we hear a lot about the expansion of Netflix and other transnational over-the-top (OTT) services, we still know very little about how cross-border VOD distribution from small EU countries is actually

\footnotetext{
${ }^{6}$ See Grece and Fontaine (2017: 14), OD-SERV (2018).

${ }^{7}$ See a May 2019 estimation by Tomáš Vyskočil, a well-informed owner of a VOD metadata aggregator (Vyskočil 2019).

${ }^{8}$ See Nowakowska (2019); see also Marcin Adamczak's chapter in this volume.
} 
accomplished on the ground and how is it changing the established practices and business models.

The only study that has tried to systematically compare cross-border circulation of European films across different distribution windows is a recent report by the European Audiovisual Observatory called The Circulation of EU Non-national Films (Grece 2017a). Although it covered only TVOD (and not SVOD or AVODad-supported video on demand) catalogues, it was able to identify a clear pattern indicating that online distribution brings a potential for wider circulation of films from small nations. While the big EU5 countries were hegemonic in the NNE film distribution in all the distribution windows, there were significant differences in the level of their domination. The average cross-border circulation of a single title fluctuated between 2.9 countries in cinemas, 1.8 in TV and 3.7 in TVOD, which means that online distribution facilitates the widest average reach. NNE in TVOD catalogues also showed the lowest dependency on international co-productions (41\% as opposed to $55 \%$ in cinemas and $51 \%$ in TV), which implied that fully national films had a better chance of traveling online than offline (Grece 2017a: 82, 90).

When compared with the theatrical and television distribution of Czech content, TVOD services facilitated an even wider international reach than the EU average quoted above: When exported inside the EU, Czech films travelled to five countries on average (as opposed to 1.0 in theatrical and 1.6 in TV distribution). This trend was similar for other CEE countries: Polish films travelled to 3.8 countries in TVOD (cinema: 1.8; TV: 1.0), Hungarian films to 3.9 (cinema: 3.7; TV: 1.1) and Slovakian to 2.9 (cinema: 1.0; TV: 1.3). At the same time, the Czech dependency on the Slovak market shrunk to $12 \%$ (exactly the same number applies to Slovakia's exports to the Czech Republic) (Grece 2017a: 35, 52, 67). Speaking strictly in terms of supply, TVOD distribution might play a positive role in widening cross-border circulation of small CEE countries' content-in comparison with not only the larger EU markets, but also some smaller Western European ones. However, as noted above, this optimism should be tempered by the fact that the actual foreign consumption and revenues are still extremely low, discouraging local players from taking a more active approach.

\subsection{Online Distribution Practices and Intermediaries}

Extensive international marketing campaigns are rare for international coproductions and virtually nonexistent for fully national Czech films. This disinterest in international marketing partly results from the low foreign revenues that producers expect. Even more importantly, though, it is a consequence of a business model that is based on producing rather than on selling their product: A typical art house producer earns most of her income from the so-called production fee, which is up to seven percent of the production budget, while the majority of the average budget consists of public subsidies and PSB investment. This production-oriented, publicly funded business model makes the producers focus on speedy development, rushing 
all projects to the shooting stage without much consideration of international markets (Szczepanik 2018). Although distribution and promotion support schemes do exist on the national as well as EU level, they are disproportionately low if compared to the volume of production grants and incentives (there are currently no specialized schemes supporting international distribution in the Czech Republic). ${ }^{9}$ For many industry insiders, this - and not the lack of potential demand-is the crucial reason for the low levels of cross-border circulation of European films.

The national orientation of film and TV production affects online distribution, too. The local distributors and producers are relatively active in getting Czech films released in the Czech VOD market, comfortably reaching the average presence of cinematic films in national VOD catalogues in the EU (62\% of EU28 films present in a VOD catalogue in at least one EU country between 2011 and 2016). ${ }^{10}$ The local leader among VOD services in terms of the volume of and revenues from recent Czech film output is Voyo, an SVOD owned by the biggest commercial broadcaster in the country. This focus on domestic VOD fits perfectly with the preexisting industry ecosystem dominated by a handful of cinema distributors, who rely on the relatively high and stable market share of Czech films in domestic theatrical distribution and who are relatively disinterested in cross-border circulation.

Indeed, interviews with industry insiders, be it producers, distributors, broadcasters, aggregators or sales agents, reveal prevailing skepticism with regard to crossborder online distribution. ${ }^{11}$ When asked about the business potential of the new distribution technologies, they generally refer to the continuing economic and cultural importance of cinema exhibition and linear TV and to the necessity of closely working with, or rather actively "building," local audiences for non-national European films. VOD distribution is considered a mere addition to the more traditional windows or a potential remedy for Internet piracy and the shrinking home video market.

Laurent Danielou (Loco Film agency), an experienced French sales agent, claims that he prefers to sell all-rights packages to local distributors territory by territory. Only when there is no chance for cinematic distribution does he sell TV or online rights separately. Exactly that happened with his latest two Slovak-Czech art house titles, which he says were difficult to sell because of their locally specific stories. Selling VOD rights, he claims, is the easiest part, although there are huge differences between different online services. He often sells TV and VOD rights to HBO Europe, which is actively looking for CEE content: "But for us it is not a glory. We are quite sad, because it means we didn't find a cinematic distributor [in the CEE territories serviced by HBO Europe]." Potentially, the most lucrative VOD partner is Netflix, whose European acquisition numbers to date, however, remain very low and which

\footnotetext{
${ }^{9}$ European public funding bodies tend to give production much higher priority than distribution and promotion: In 2009, they spent only $8.4 \%$ of their budget on distribution and $3.6 \%$ on promotion schemes on average, in contrast to $69.9 \%$ spent on production. See European Commission (2014). ${ }^{10}$ For pan-EU statistics, see Fontaine (2019a, b); data on the Czech films on VOD platforms were compiled from the Czech VOD database Filmtoro.cz.

${ }^{11}$ Similarly to Poland and Greece, as shown in Marcin Adamczak's and Lydia Papadimitriou's chapters in this volume.
} 
has a small acquisition team acting from a long distance, not expected to attend special screenings presenting national productions from the CEE to invited industry guests, so important, Danielou stresses, for closing international distribution deals. ${ }^{12}$ It is difficult to build personal ties with them, and most of the time the sales agent is just waiting for Netflix to make a rare arbitrary choice from files he has been sending to them routinely. Although selling films to Amazon Prime is supposedly much easier for a European sales agent, Danielou remains skeptical about how many people actually see his titles from Amazon catalogues. Overall, he acknowledges that VOD revenues remain negligible: "For us, VOD is not a real market yet."13

The majority of Czech audiovisual online export - unlike cinematic distributionis organized directly from Prague, without a foreign distributor or sales agent. The three major intermediaries are the Czech public service broadcaster "Česká televize" (mostly for documentaries and TV series) and the two biggest Czech home video distributors, AQS and Bontonfilm, who since 2015 have held iTunes and Google Play direct aggregation licenses and act as both domestic and international digital distributors and aggregators for Czech producers. When trading Czech films, AQS and Bontonfilm typically buy either territorial or global online rights for specific VOD services (mostly iTunes), excluding —if applicable_-foreign co-producers' territories. Ondřej Kulhánek, the director of theatrical and digital distribution at Bontonfilm, claims that territorially limited licenses exclusive for iTunes and Google Play are the most common type. The distributors upload different language versions of individual titles (via an iTunes-approved encoding house taking care of the technical process of preparing and controlling the files according to the portals' requirements), fill in metadata, set prices, release dates (first a more expensive download to own and then cheaper rental) and "turn on" the titles in selected territorial catalogues. AQS' home video and VOD distribution managing director Jan Rubeš points out that practical limits for entering foreign territories via iTunes or Google Play catalogues are often set not by territorial licensing, because Czech producers usually do not expect or plan wide international sales, but by the lack of foreign language versions apart from the obligatory English. Although iTunes allows English-only localizations to be distributed to 64 territories including the Czech Republic, it still requires local language versions in the remaining territories such as France or Italy, and the financial burden on producers might not be recoverable through online sales. Rubeš follows sales numbers in individual territories and appreciates the quite significant year-over-year growth of AQS' total online revenues, but so far he has not launched any online marketing campaigns targeting foreign territories. Kulhánek adds that Bontonfilm has by far the best experience with iTunes, and it employs iTunes-enabled promotional instruments and discounts, although these focus mostly on the domestic territory. ${ }^{14}$

\footnotetext{
${ }^{12}$ The volume of European films produced or acquired by Netflix is expected to rise to comply with the 30\% quotas introduced by the new Audiovisual Media Services Directive (Thomson 2019b).

${ }^{13}$ A Skype interview with Danielou Laurent (Loco Films) conducted by Petr Szczepanik, February 22, 2019.

${ }^{14}$ An interview with Ondřej Kulhánek conducted by Petr Szczepanik and Pavel Zahrádka, January 31, 2017; an interview with Jan Rubeš conducted by Pavel Zahrádka and Jan Hanzlík, August 23, 2018.
} 
The bulk of the foreign sales of Czech Television content is managed by Česká televize via its sales department, which practically functions as the PSB's in-house sales agent. The department's head, Luboš Kř́žz, has observed significant changes that came with digitalization and the advent of VOD: the diversification and multiplication of buyers, the decrease in licensing prices and unexpected interest from new territories such as Japan and Brazil. Česká televize is focusing primarily on TV rights, selling them directly to foreign broadcasters, together with catch-up and VOD rights, omitting other intermediaries (international sales agents, Czech and foreign distributors) and limiting the scope of rights as much as possible, typically to a single territory and for three years, with an option of reselling in the same territory. While TV rights are sold exclusively, online rights tend to be non-exclusive, to allow other players in a territory to license them, and they are occasionally sold worldwide. Unlike the above-mentioned home video distributors, Česká televize focuses on VOD services that are able to pay a flat fee or at least a minimum guarantee. If a co-production agreement divides world rights between Česká televize and an independent producer, the PSB usually takes former socialist countries that it has historically exported to. According to Kř́̌ž, TV series generally sell better (in terms of TV rights) than films, which need to be grouped into packages (often mixing older and newer titles) to satisfy foreign broadcasters' programming needs. ${ }^{15}$ But while Česká televize, taking advantage of its vast library, is the biggest exporter of Czech audiovisual content in terms of the total annual export volume (selling hundreds of titles per year mostly to broadcasters),${ }^{16}$ the presence of its serial content in foreign VOD catalogues seems to be much smaller when compared to independent films. ${ }^{17}$

The most renowned and internationally established Czech art house production company, Negativ Film, has the widest online presence in the foreign VOD catalogues mapped for this chapter: Its titles regularly reach not just the big global TVOD catalogues, but also HBO GO in Europe, smaller mainstream services such as Pantaflix in Germany and Vudu in the USA, free AVODs such as Tubi TV, public library and educational services such as Hoopla and Kanopy, and niche art house and documentary portals such as UniversCiné and Feelmakers. Negativ's sales executive Daniel Vadocký acknowledges that although he has been working with several VODs directly, for international sales he still strongly prioritizes cinematic deals, relying on foreign sales agents and above all foreign distributors with well-developed local knowledge and networks of contacts to handle not just theatrical, but also foreign TV and online distribution of his portfolio, too. An experienced international sales agent is not necessary in the neighboring CEE territories such as Slovakia or Poland but makes a big difference in large lucrative markets such as France or the USA, in terms of selecting and connecting with the right local partners, while the local foreign distributor is vital for choosing local online services as well as efficiently collecting revenues, however small they may be. The Czech producer then tends to trust the sales agent or foreign distributor without interfering with or even monitoring their

\footnotetext{
${ }^{15}$ An interview with Luboš Kř́̌̌z conducted by Petr Szczepanik, October 12, 2018.

${ }^{16}$ Apart from Czech-made pornography, which this chapter leaves out.

${ }^{17}$ See www.justwatch.com.
} 
operations beyond the obligatory financial reporting, which does not detail results for individual VOD services: "As soon as our film is bought by a foreign distributor, I completely lose track of where exactly it goes in terms of VOD." For example, Ice Mother, the comedy drama about unlikely love between two aging people, directed by the internationally best known Czech art house director Bohdan Sláma, the latest success from Negativ (and the Czech Republic's submission to the Oscars), was picked by the renowned sales agency The Match Factory, which sold all North American rights to the distributor FilmRise. Negativ was able to check the deal, but that is where their tracking of the process ended. FilmRise acknowledged right away that their plan for the USA was to skip theatrical distribution, publish DVDs and then go directly online (they eventually also helped with the Oscar campaign). FilmRise teamed up with the aggregator Quiver and launched a wide online release in the USA including Amazon Prime, iTunes, Google Play, Vudu and YouTube. Vadocký says he believes that FilmRise is doing their best to get the movie to as many online retailers as possible, but he also acknowledges that their strategy is rather "quantitative," pushing Ice Mother to the same well-proven VOD services as any other European art house title rather than tailoring the release for the film's specific qualities. According to Vadocký, revenues generated from foreign TVODs are still discouragingly small for him to engage in more active planning or monitoring of foreign online sales: "The work load required to get a film to a foreign VOD is too heavy for practically zero money. Even from the biggest portals we get monthly just one or two hundred CZK per title." For him, more important than the number of territories and VOD services is visibility in the market. Vadocký describes Netflix as "currently the best partner in purely financial terms," but quickly adds that he regrets it is so and that he prefers cultivating good relationships with Negativ's traditional cinematic partners and submitting to the Cannes Film Festival, which is notoriously at odds with Netflix. Overall, Negativ's approach is based on preserving control of international rights and tailoring foreign sales strategies for individual titles by exposing them to key decision-makers at international markets and festivals early on, ideally from the development stage. ${ }^{18}$

Unlike Negativ, which avoids working with domestic distributors and broadcasters in its foreign sales strategy, most producers, especially of a more commercially oriented breed, do not have their own sales executives. Instead of tailoring international marketing campaigns for each title before it is produced, they rely on one of the two biggest Czech home video distributors, Bontonfilm or AQS, to take care of both domestic and international online sales. Miloslav Šmídmajer, the owner of the Bio Illusion production house, is currently ${ }^{19}$ one of the most active sellers of foreign online rights among independent, commercially oriented producers (he specializes in family comedies and animation). He is contracting either small international sales agents (such as London-based Amadeus Entertainment, specializing in genre films from Russia and Eastern Europe) or the Czech distributor AQS to sell his more

\footnotetext{
${ }^{18}$ An interview with Daniel Vadocký (Negativ Film), May 16, 2019.

${ }^{19}$ Judging from the data sample compiled from the four territories for this chapter.
} 
attractive titles across borders. At the same time, he sells a package of his less internationally appealing titles directly via Amazon, with the help of a small and virtually unknown Czech sales agent specializing in the Hungarian market (the agent is not credited in foreign Amazon catalogues), with whom he shares aggregator fees and revenues: "without the agent, I would not bother going into this." With the least internationally attractive titles, Šmídmajer decides not to produce English language versions at all. Outside big Western markets, he reports a rise of interest in TV and online rights for Czech content from the Middle East, South America and above all China, where Czech films usually end up in larger packages of cheaper content without the option of monitoring the actual revenues. ${ }^{20}$ But despite these signs of progress, Šmídmajer considers foreign online sales negligible, "a joke," reaching no more than hundreds of CZK per year per title. None of Šmídmajer's titles distributed online across borders was able to cover even the aggregator fee. ${ }^{21}$

\subsection{TVOD's Extensive, Bottom-Up Distribution Model}

As these interviews illustrate, transnational TVOD services have been able to seamlessly integrate into the local industry ecosystem: They have been easier to approach than SVODs, perfectly compatible with the traditional local intermediaries, and they have been disrupting the established distribution practices less than Netflix. At the same time, they also allow local independent producers to upload their films directly, under the condition of observing basic technical and localization standards. Crossborder TVOD distribution therefore opens a space for more diverse set of distribution practices and intermediaries.

The most extensive and diverse portfolio of Czech films abroad is made available by iTunes and Amazon (both TVOD Amazon Video and SVOD Amazon Prime Video). ${ }^{22}$ There is no apparent logic behind the selection, which includes all kinds of domestic production. The dataset compiled for this chapter does not allow for a full-scale comparative analysis across the CEE region, but the European Audiovisual Observatory's reports indicate that Czech producers and distributors are using transnational TVOD services more often than their counterparts in other Central and Eastern European territories. In 2018, the number of Czech films in European TVOD catalogues surpassed that of any other post-socialist EU country except Lithuania, although it still represented just $0.5 \%$ of titles in European TVOD catalogues. It also surpassed most post-socialist countries (apart from Bulgaria and Romania) and many West European countries in terms of average country circulation (3.9 countries

\footnotetext{
${ }^{20}$ This is in line with a more general trend in the EU: China was identified as the largest non-European market for European films (in terms of cinema admissions) in a recent EAO study (Kanzler and Simone 2019: 157).

${ }^{21}$ A telephone interview with Miloslav Šmídmajer (Bio Illusion), July 12, 2019.

${ }^{22}$ The US and German Amazon Video catalogues include two to three times more Czech titles than Amazon Prime Video, which is why Amazon is discussed in the TVOD section rather than as SVOD.
} 
and per title-as opposed to 1.1 countries per Czech title in SVOD catalogues). At the same time, the Czech iTunes catalogue contained at least ten times more local titles than in Poland, Hungary, Slovakia or any other post-socialist country in the EU, even though the Czech share was still two times less than iTunes' average share of national titles in the EU and many times lower than the national share in the EU5 (Grece 2019: 56-59, 76). Interviews indicate that the driver behind this prominent position of TVOD and iTunes in particular is not international interest in local production but the two above-mentioned Czech home video distributors' active role as local aggregators of online rights and iTunes' contractual partners (Figs. 9.1, 9.2, 9.3 and 9.4).

One of the key differences between transnational SVOD and TVOD services is their strategies for acquisition and original content. Google Play and Apple's iTunes have no original local content at all. Although Amazon has launched an aggressive local production campaign in Europe, it has not produced any original content in the CEE region and it has no visible local presence in terms of VOD representatives. For the most part, these TVODs operate as bottom-up catalogues without any specific content acquisition strategy apart from standardized quality control that has been partly outsourced to "approved" aggregators such as Quiver or Distribber. To get a movie into Amazon or iTunes' catalogue, for example, a producer does not necessarily need a distributor, which opens the door for indie and foreign titles that would not have been picked by big international distributors. The self-distribution model requires the producer to secure localization and typically to pay an upfront fee for the services of an aggregator (some of the aggregators ask for a share of revenues, too), who will take care of the ingestion, encoding and quality control. Despite this option, producers still mostly use intermediaries: A local home

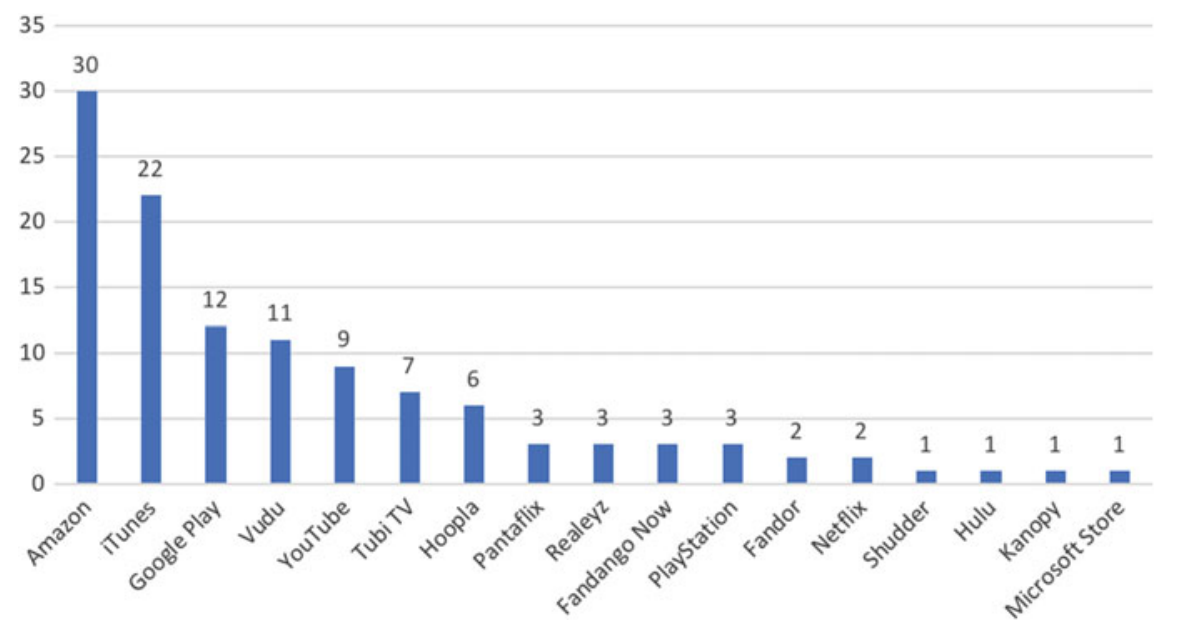

Fig. 9.1 Recent Czech feature fiction films (2011-2018) in the US Online Distribution, as of March 2019 (Source Data based primarily on an analysis of search results from Justwatch.com and Amazon.com) 


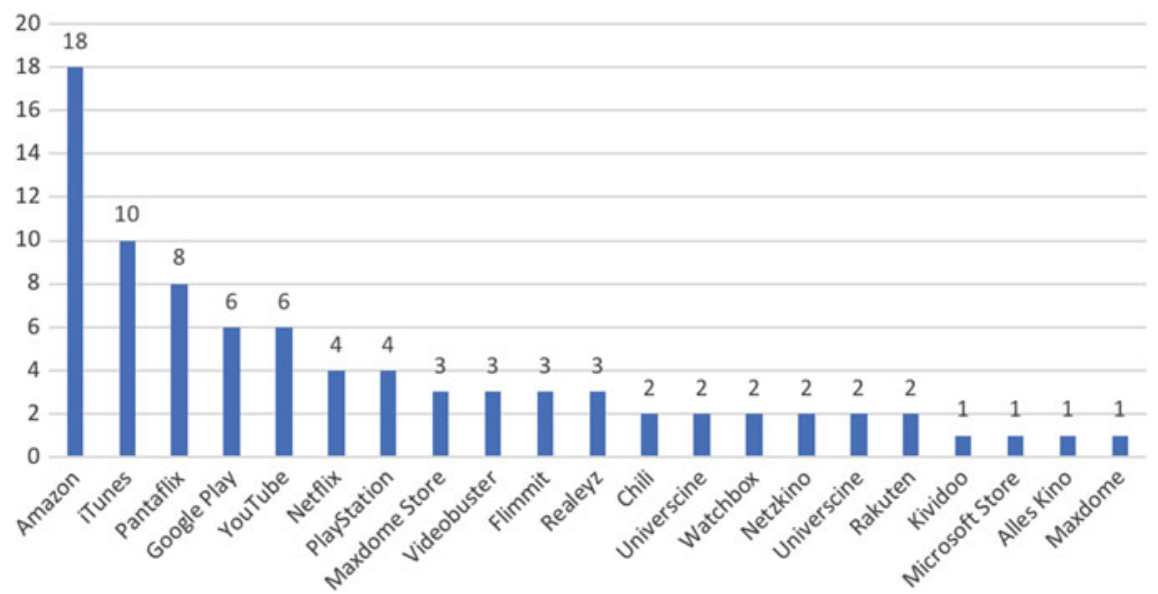

Fig. 9.2 Recent Czech feature fiction films (2011-2018) in the German Online Distribution, as of March 2019 (Source Data based primarily on an analysis of search results from Justwatch.com)

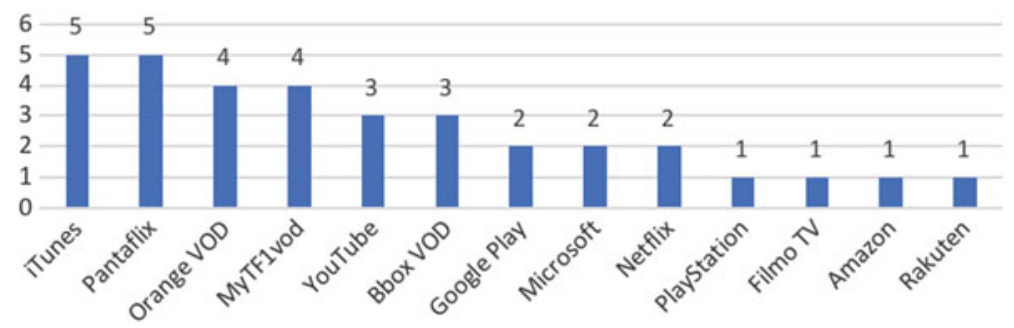

Fig. 9.3 Recent Czech feature fiction films (2011-2018) in the French Online Distribution, as of March 2019 (Source Justwatch.com)

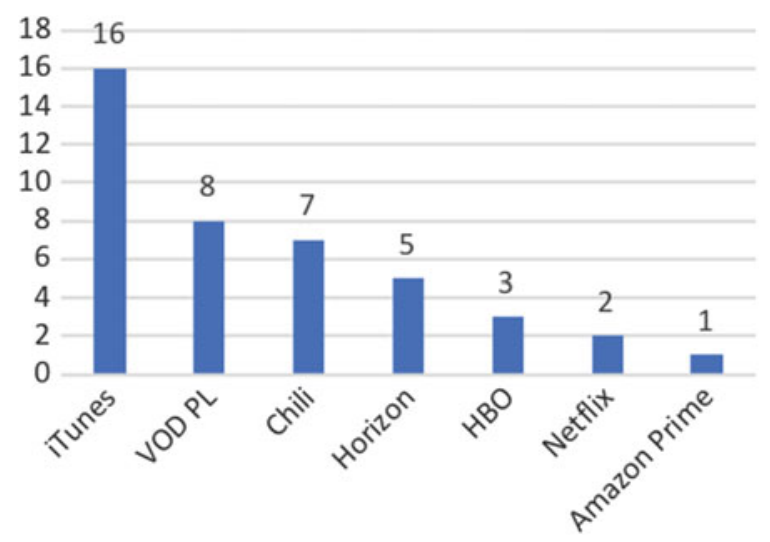

Fig. 9.4 Recent Czech feature fiction films (2011-2018) in the Polish Online Distribution, as of March 2019 (Source Justwatch.com) 
video distributor or a foreign digital distributor, who might submit the title to several VOD services simultaneously, takes care of its editorial placement as well as giving it very modest marketing support. Different VOD services offer different financial conditions: While iTunes splits the sales 70:30 in favor of the producer, Amazon's self-distribution platform Amazon Video Direct applies a revenue-sharing program based on either a 50:50 split (for titles purchased or rented on Amazon) or per-hour revenue rates from an Amazon Prime subscription (ranging from $\$ 0.06$ to $\$ 0.15 / \mathrm{h}$ depending on the total number of streaming hours). All above-mentioned VODs also rely on unique discovery algorithms which favor titles supported by strong marketing campaigns, typically US-produced blockbusters and festival winners. IndieWire sums up the frustrating experience of an indie film producer with the Amazon algorithm: "If I wasn't dead set on finding it, I would have given up and ordered something else" (Newman 2017). This implies that a Czech film without festival awards and proper marketing support, or at least without mobilizing its online fan base, would probably have little chance of recovering the aggregator fee that may range between $\$ 1000$ and $\$ 1500$ per title (Guerrasio 2018).

\subsection{SVOD's Intensive, Top-Down Model and the Original Local Content Production}

Transnational SVOD services Netflix and HBO do not have self-distribution platforms; their acquisition is much more selective, with Netflix being especially difficult to approach for local legacy media players and more disruptive to their established practices. This is even more so in the CEE region where Netflix catalogues include close to zero local content (Grece 2019: 112). At the same time, these transnational SVODs are able to offer better financial conditions, personalized marketing support and higher symbolic prestige.

Transnational SVODs_-which, unlike TVODs, typically require pitching-pose a different kind of challenge to Czech producers. Negativ's sales executive Daniel Vadocký reports successful and regular negotiations with HBO Europe, whose Czech branch has co-produced several of Negativ's documentaries and bought online rights for Negativ's entire library of older titles, supposedly in a move to counter Netflix by buying out local content (as of July 2019, HBO GO's catalogues in Romania and Hungary include Negativ's 15 fiction features and a few documentaries from 1995 to 2017). But his experience with Netflix follows the well-known story of the difficulties with even contacting the right acquisition executives seated in Los Angeles, searching for the necessary help from intermediaries and then waiting helplessly for their arbitrary decision, which tends to be negative. ${ }^{23}$

HBO Europe is different from Netflix's European operations in terms of its longterm local presence and deep embeddedness in Central and Eastern Europe, which recently expanded into 21 European territories across the continent. HBO's first

\footnotetext{
${ }^{23}$ An interview with Daniel Vadocký (Negativ Film), May 16, 2019.
} 
overseas branches opened in Hungary, Poland, Czech Republic and Romania in the early-to-mid-1990s; in the mid-to-late 2000s, they started acquiring and co-producing local stand-ups, documentaries and feature films. In 2010, HBO moved into in-house production of high-end series in the Czech Republic, Hungary, Poland and Romania (and more recently, it started producing original series also in its HBO Adria, HBO Nordic and HBO Espana branches). HBO Europe has been carefully cultivating its relationships with prominent local talent and legacy media players, creating a sense of trust and even admiration for its "creative freedom" approach among the regional professional communities. Since the launch of HBO GO, and especially since its recent conversion to OTT in the CEE region (in November 2017), its local originals have become a key instrument in competition with Netflix. ${ }^{24}$ While HBO Europe aims at releasing its European originals day-and-date across all 21 countries, and while the local HBO Europe catalogues contain the most recent HBO US original titles, local HBO production does not automatically get into the catalogues of HBO US or other HBO territories outside Europe. For its most successful local title so far, the three-part miniseries The Burning Bush (2013), HBO Europe teamed up with the German sales agency Beta Film, one of the largest traders with film and TV rights outside the USA and a pioneer of the high-end local TV content production trend in Europe. Beta Film managed to sell The Burning Bush to at least 40 foreign territories, including prominent broadcasters such as Arte Germany and France, RAI and HBO Latin America, and VODs such as iTunes, Google Play, PlayStation Store, Hoopla, Sundance Now, Maxdome and Filmmit. ${ }^{25}$ Several HBO Europe series have also made it into HBO US catalogues (e.g., HBO Czech's Wasteland and HBO Romania's The Silent Valley), which HBO Europe's executive VP of original programming and production Antony Root considers a groundbreaking success (Tizard 2018). The example of HBO Europe shows that the recent boom in original local production of transnational VOD services can significantly change the map of cross-border circulation from small media markets by opening up even the most exclusive distribution channels for them, although still only in a very limited scope.

Netflix's selection of local content is much narrower than HBO's, and the company is also much less transparent and predictable in terms of its acquisition strategy and curation. Netflix has dramatically raised its investment in original European production [to about a billion dollars in 2018, with 221 European projects planned for 2019—-see Gold (2019)], but it has also become notorious for overusing the label "Netflix original." The label can refer to shows commissioned and produced by Netflix, but also to co-productions with other networks or even to exclusive international streaming rights. In the Czech Republic, Netflix has limited its selection to just one feature acquisition and one co-funded production in its first three years of local operation. ${ }^{26}$ The Devil's Mistress, a biopic about a Czech interwar actress who had an

\footnotetext{
${ }^{24}$ An interview with the former head of HBO Czech Ondřej Zach, December 18, 2017.

${ }^{25}$ See the discussion with HBO Czech Republic's production executive (Czech Television 2017). See also TBI Reporter (2014).

${ }^{26}$ In October 2019 (i.e., beyond the time frame of this chapter), Netflix localized its interface in the Czech Republic and bought a package of about 30 older and newer Czech films, limiting their
} 
affair with Joseph Goebbels, was the first Czech feature film acquired by Netflix for global distribution. The deal was announced half a year before Netflix launched its local service (Sedlák 2015). Milada is the story of a female social democratic MP executed after a communist show trial in the early 1950s, shot in English with an international cast by first-time director David Mrnka. Mrnka, who has worked in the US television industry (as a producer for Larry King Live and BBC World News, but not on any high-profile fiction projects), claimed that Netflix got involved during script development and acquired worldwide rights except for several territories including the Czech Republic (Czech Film Center 2017).

Although Netflix featured-until very recently - a very narrow and arbitrary selection of CEE content, it is still possible to find some regularities and significant differences across the region. In Poland, only one feature film plus one fiction and several nonfiction TV series went into global distribution via Netflix (as of February 2019). The feature film, a biopic about a Polish female gynecologist called The Art of Loving, shows striking similarities with the two Czech films discussed above, also stories about strong, real-life female characters against the background of the national political history. Milada, The Devil's Mistress and The Art of Loving are labeled with the same Netflix genre categories: "Movies based on Real Life," "Biographical Movies," "Czech/Polish Movies." None of these films was produced by a producer or a director with a strong international reputation, so it can be expected that the deals were relatively cheap for Netflix. However, a closer look at different national catalogues reveals that Netflix is not treating all the CEE markets in the same way. In Poland, it co-produced a high-budget series called 1983, a dystopian alternative history of Poland in 2003 under continuing communist rule, directed by Agnieszka Holland, who had previously worked for HBO (including the abovementioned Czech miniseries The Burning Bush). Indeed, the series seems to directly compete with HBO Europe's most prestigious projects, which also draw on national political histories and feature prominent local stars. Apart from that, Netflix has shot a serial adaptation of the globally known Polish fantasy saga The Witcher in English and was negotiating a historical crime series co-production with the PSB Telewizja Polska based on the Polish novel Erynie (Rutkowska 2019). Netflix has also acquired about 20 Polish films, mostly comedies from the 2000s, two fictions and one nonfiction TV series, and commissioned a series of "Netflix Branded Original Stand Up Specials" with Polish comedians. Most of these acquired films and TV series, however, have been available only in the Polish Netflix catalogue, and they show signs of being purchased as cheap packages from several local distributors. ${ }^{27}$ Hungary is treated still differently from the Czech Republic and Poland: as a source of exportable art house films with strong symbolic capital. A small group of awardwinning titles such as Son of Saul, On Body and Soul, White God and Kills on Wheels

distribution to the Czech and/or Slovak catalogue, with several exceptions being added also to the Hungarian, Romanian and/or Polish catalogues. This means that even after this leap, Milada and The Devil's Mistress remain the only Czech titles acquired by Netflix for a wide international distribution. See https://unogs.com.

${ }^{27}$ See https://unogs.com. 
have been bought for a diverse set of Netflix catalogues, including, respectively, the USA, Japan, India and Mexico. Slovakia seems to be a blind spot, with no local content and no localization (after petitioning Netflix, Slovak fans could at least access Czech localization from February 2019).$^{28}$ Despite its fast move into the region in its 2016 "global switch on" and despite the first round of arbitrary choices described above, Netflix is showing signs of treating different CEE markets in a slightly more nuanced way: Poland as a pool of stories and talent for exportable high-end series, Hungary as a source of auteur cinema that can be of interest to Netflix's global cosmopolitan audiences, Slovakia as too small to bother and the Czech Republic as a country whose totalitarian history is more exportable than its cinema.

\subsection{Conclusion}

This inquiry into the practices and players involved in cross-border online distribution from CEE markets shows how diversified, unstable and locally specific the impacts of transnational VOD services are. The charts of Czech films in foreign territories change our perception of how and where CEE films travel online (outside Slovakia): Instead of France, Poland and Germany, which are the biggest importers in theatrical and TV distribution (Grece 2017a: 35, 52), the largest number of Czech films gets to the USA. They also point to the fact that the debate about the global VODs should not be concentrated on Netflix alone. While Netflix attracts the most attention, it is iTunes, Amazon and Google Play, followed by some lesser-known services such as Vudu and Pantaflix that facilitate the widest cross-border circulation of CEE content. While Netflix hails its own original content investments in Europe, it is still HBO that produces and buys more local content in the CEE region and distributes it across borders to its 21 European territories. While Netflix speaks of aggressive localization campaigns, until recently it has been one of the least localized global services with the smallest share of local content, either locally produced or acquired in the Czech Republic (see Table 9.1).

The analysis shows that it is crucial not to take the general quantitative statistics on VOD distribution at face value. A closer look at how online distribution is actually done "on the ground" reveals the emergence of a new distribution hierarchy in terms of marketing power, symbolic prestige and potential revenues. It is not enough to distinguish between SVOD, TVOD and AVOD—we need to look at individual services, their evolving business models, their algorithms, key intermediaries and different tiers of content including titles self-distributed by producers via Amazon's Video Direct. The strongly promoted and highly prestigious local HBO productions sit at the opposite end from the self-distributed, fully national (and otherwise non-exportable) productions buried in iTunes' or Amazon's catalogues. The online distribution regimes described in the above analysis can be hierarchically ordered as

\footnotetext{
${ }^{28}$ The Czech language is widely understood among the Slovak population. See VelkyObsah.info and Filmtoro.sk (2019).
} 
Table 9.1 Comparative overview of transnational VOD services operating in the Czech Republic, as of March 28, 2019

\begin{tabular}{l|l|l|l|l|l}
\hline $\begin{array}{l}\text { Transnational } \\
\text { VOD service }\end{array}$ & $\begin{array}{l}\text { Business } \\
\text { model and } \\
\text { distribution } \\
\text { technology }\end{array}$ & $\begin{array}{l}\text { The size } \\
\text { of local } \\
\text { catalogue } \\
\text { (all titles) }\end{array}$ & $\begin{array}{l}\text { Original local } \\
\text { content }\end{array}$ & Acquisitions & Localization \\
\hline HBO & $\begin{array}{l}\text { Pay TV/OTT } \\
\text { SVOD }\end{array}$ & 1562 & $\begin{array}{l}29 \text { films } \\
\text { fiction and } \\
\text { documentaries) } \\
\text { and 6 TV } \\
\text { series }\end{array}$ & $\begin{array}{l}14 \text { films } \\
\text { (fiction and } \\
\text { documentaries) }\end{array}$ & $\begin{array}{l}100 \%: \\
\text { dubbing and } \\
\text { subtitles }\end{array}$ \\
\hline Netflix & OTT SVOD & 4956 & 1 fiction film & 1 fiction film & $\begin{array}{l}0.5 \% \\
\text { dubbing and } \\
9 \% \text { subtitles }\end{array}$ \\
\hline $\begin{array}{l}\text { Amazon } \\
\text { Amazo, and } \\
\text { Prime }\end{array}$ & $\begin{array}{l}\text { OTT } \\
\text { TVOD/SVOD }\end{array}$ & 999 & - & 3 fiction films & $\begin{array}{l}3 \% \text { dubbing } \\
\text { and 3\% } \\
\text { subtitles }\end{array}$ \\
\hline Google Play & OTT TVOD & 3598 & - & $\begin{array}{l}36 \text { films } \\
\text { (fiction and } \\
\text { documentaries) }\end{array}$ & $\begin{array}{l}17 \% \\
\text { dubbing and } \\
28 \% \\
\text { subtitles }\end{array}$ \\
\hline iTunes & OTT TVOD & 8633 & - & $\begin{array}{l}159 \text { fiction } \\
\text { films }\end{array}$ & $\begin{array}{l}35 \% \\
\text { dubbing and } \\
22 \% \\
\text { subtitles }\end{array}$ \\
\hline
\end{tabular}

Source Data compiled from the database Filmtoro.cz (The process of localization of the Czech Netflix catalogue has sped up significantly since March 2019 [0.7\% dubbed and over 16\% subtitled as of August 2019, with more titles being localized later that year])

follows (from the highest level of international exposure and prestige to the lowest): (1) transnational SVODs' local productions and exclusive acquisitions with strong marketing support (such as HBO's The Burning Bush and Netflix's Milada); (2) mostly festival-oriented, often internationally co-produced art house films picked by renowned foreign sales agents (such as films produced by Negativ Film Productions and directed by Bohdan Sláma) and distributed through a wide variety of VOD services with the help of foreign local distributors; (3) mostly fully national films with limited international appeal, whose TVOD rights are sold by local home video distributors (the two Czech leaders in the home video market: Bontonfilm and AQS); and (4) even less internationally appealing, mostly commercially oriented fully national productions, self-distributed abroad by Czech producers via foreign or domestic aggregators, ${ }^{29}$ and limited to TVOD.

\footnotetext{
${ }^{29}$ The key difference between a digital distributor and an aggregator is that the former buys and sells a license, while the latter just charges a fee for services necessary to upload a movie to a VOD catalogue.
} 
It is likely that transnational flows from peripheral and/or small media markets in the CEE will be dependent on the changing strategies of global VOD services. With new global players and increased competition expected and with local content production initiatives anticipated to further boom, it seems that the circulation trajectories of CEE content will diversify, too. The prospect that micro-groups of audiences interested in peripheral content and scattered across the globe can be compiled just by placing the content into numerous TVOD catalogues seems utopian. More targeted production and marketing investment will be required to improve the circulation of CEE content. The legacy media players and public institutions in Central and Eastern Europe that have remained skeptical and hesitant to invest in cross-border online distribution will need take a more active approach. It remains to be seen whether the European Commission's DSM strategy will be successful by introducing content quotas, levies, prominence and transparency obligations, pushing the global giants to be more receptive to national audiovisual cultures and simultaneously to start revealing data about their catalogues, revenues and discovery algorithms. In the meantime, online distribution studies will have to keep developing methods that compensate for the secretive, black-box approach of most VOD services. ${ }^{30}$

\section{References}

Aguiar, L., \& Waldfogel, J. (2018). Netflix: Global hegemon or facilitator of frictionless digital trade? Journal of Cultural Economics, 42(3), 419-445.

Alaveras, G., Gomez-Herrera, E., \& Martens, B. (2018). Cross-border circulation of films and cultural diversity in the EU. Journal of Cultural Economics, 42(4), 645-676.

Czech Film Center. (2017). This story really needs to get out! Czech Film Center, 3 November. www.filmcenter.cz/en/news/1347-this-story-really-needs-to-get-out. Accessed August 15, 2019.

Czech Television. (2017). Discussion with Tereza Polachová. Facebook, 31 July. https://www. facebook.com/ceskatelevize/videos/10154870705407686. Accessed November 11, 2019.

De Vinck, S., \& Pauwels, C. (2015). Beyond borders and into the digital era: Future-proofing European-level film support schemes. In I. Bondebjerg, E. N. Redvall, \& A. Higson (Eds.), European cinema and television: Cultural policy and everyday life (pp. 102-123). Basingstoke: Palgrave Macmillan.

European Commission. (2014). Communication to the European Parliament, the Council, the European Economic and Social Committee and the Committee of the Regions -European Film in the Digital Era Bridging Cultural Diversity and Competitiveness, COM(2014) 272 final. https://eur-lex.europa.eu/legal-content/EN/TXT/PDF/?uri=CELEX: 52014DC0272\&from=EN. Accessed November 11, 2019.

European Parliament. (2012). Resolution on the online distribution of audiovisual works in the European Union (2011/2313(INI)). https://www.europarl.europa.eu/sides/getDoc.do?pubRef=-//EP// NONSGML+TA+P7-TA-2012-0324+0+DOC+PDF+V0//EN. Accessed November 11, 2019.

Fontaine, G. (Eds.). (2019a). Yearbook 2018/2019: Key trends. Strasbourg: European Audiovisual Observatory.

\footnotetext{
${ }^{30}$ This study was supported by the European Regional Development Fund Project "Creativity and Adaptability as Conditions of the Success of Europe in an Interrelated World" (No. CZ.02.1.01/0.0/0.0/16_019/0000734).
} 
Fontaine, G. (2019b). Update on VOD markets and catalogues. Strasbourg: European Audiovisual Observatory.

Gold, H. (2019). 2019 is the year the streaming wars get real. CNN Business, 11 January. https://edition.cnn.com/2019/01/11/media/tv-streaming-2019-netflix-disney-apple/index. html. Accessed August 15, 2019.

Grece, C. (2017a). The circulation of EU non-national films. Strasbourg: European Audiovisual Observatory.

Grece, C. (2017b). The origin of films in VOD catalogues. Strasbourg: European Audiovisual Observatory.

Grece, C. (2019). Films in VOD catalogues: Origin, circulation and age (2018 ed.). Strasbourg: European Audiovisual Observatory.

Grece, C., \& Fontaine, G. (2017). Trends in the EU SVOD market. Strasbourg: European Audiovisual Observatory.

Guerrasio, J. (2018). Independent filmmakers are irate after Amazon slashed royalties by $60 \%$ on its self-distribution platform. Business Insider, 21 February. www.businessinsider.com/amazonvideo-direct-plans-to-drastically-change-its-royalty-amount-2018-2. Accessed August 15, 2019.

Hastings, R. (2016). Keynote. The Netherlands EU Presidency Conference "Promoting CrossBorder Circulation of European Audio-Visual Content”, 3 March. www.youtube.com/watch?v= ZKdIT70gH6s. Accessed August 15, 2019.

Higson, A. (2018). The circulation of European films within Europe. Comunicazioni Sociali, 3, 306-323.

Holdaway, D., \& Scaglioni, M. (2018). From distribution to circulation studies: Mapping Italian films abroad. Comunicazioni Sociali, 3, 341-355.

Iordache, C., Van Audenhove, L., \& Loisen, J. (2018). Global media flows: A qualitative review of research methods in audio-visual flow studies. Communication Gazette, 81(7), 1-20.

Kanzler, M., \& Simone, P. (2019). Focus 2019: World film market trends. Strasbourg: European Audiovisual Observatory.

Lobato, R. (2018). Rethinking international TV flows research in the age of Netflix. Television \& New Media, 19(3), 241-256.

Newman, B. (2017). Why Netflix and Amazon algorithms are destroying the movies. IndieWire, 12 July. www.indiewire.com/2017/07/netflix-amazon-algorithms-destroying-themovies-1201853974. Accessed August 15, 2019.

Nowakowska, J. (2019). O polskich subskrypcjach z serialami w tle. Screen Lovers, 18 February. https://screenlovers.pl/o-polskich-subskrypcjach-z-serialami-w-tle-raport-z-frontusvod. Accessed August 15, 2019.

OD-SERV. (2018). Households subscribing to SVOD in Europe (2013-2017). European Audiovisual Observatory. https://yearbook.obs.coe.int/s/document/5522/od-serv-unique-subscribers-toott-svod-services-in-europe-2013-2017. Accessed August 15, 2019.

Rutkowska, E. (2019). Netflix negocjuje z TVP. Dziennik.pl, 28 March. https://wiadomosci. dziennik.pl/media/artykuly/594516,netflix-tvp-negocjacje-serial-powiesc-krajewski.html? fbclid=IwAR3Mwy1aU2d8GShhCQcU5jm3hgPH0PZwK6FcVS8dylGa_RzgZiHldNTYYp8. Accessed August 15, 2019.

Sedlák, J. (2015). Netflix koupil práva na Renčův film Lída Baarová. E15, 10 August. https://www. e15.cz/magazin/netflix-koupil-prava-na-rencuv-film-lida-baarova-1217149. Accessed August $15,2019$.

SPI Olsberg. (2019). Priority international markets for Czech producers, Prague: APA.

Szczepanik, P. (2018). Post-socialist producer: Production culture of a small-nation media industry. Critical Studies in Television, 13(2), 207-226.

TBI Reporter. (2014). HBO hang hopes on Euro dramas. TBI, 6 October. https://tbivision.com/ features/2014/10/hbo-hangs-hopes-euro-drama/337901. Accessed August 15, 2019.

Thomson, S. (2019a). CEE SVOD set to more than double. Digital TV Europe, 1 May. www. digitaltveurope.com/2019/05/01/cee-svod-set-to-more-than-double. Accessed August 15, 2019. 
Thomson, S. (2019b). Ampere: Netflix will "aggressively ramp up" local production in Europe and Asia. Digital TV Europe, 8 January. www.digitaltveurope.com/2019/01/08/ampere-netflix-willaggressively-ramp-up-local-production-in-europe-and-asia. Accessed August 15, 2019.

Tizard, W. (2018). HBO's Antony Root on creating European shows for a global audience. Variety, June 28. https://variety.com/2018/tv/global/hbo-antony-root-europe-1202860572. Accessed August 15, 2019.

VelkyObsah.info, \& Filmtoro.sk. (2019). Netflix, make Czech localisation available in Slovakia: A petition. Change.org. https://chng.it/pdexGWsh. Accessed August 15, 2019.

Vysko cil, T. (2019). Kolik lidí má u nás Netflix? Filmtorbttps://filmtoro.cz/blog/kolik-lidi-ma-unas-netflix-jaka-je-nabidka-a-kolik-filmu-ma-titulky-mame-novou-studii. Accessed August 15, 2019.

Petr Szczepanik is Associate Professor at Charles University, Prague. He has written books on the Czech media industries of the 1930s and on the state-socialist production mode. His current research focuses on (post-)socialist producer practices in Central and Eastern Europe. Some of his findings are published in Behind the Screen: Inside European Production Culture (Palgrave, co-edited with Patrick Vonderau, 2013). He led the EU-funded FIND project (2012-2014), which used student internships for a collective ethnography of production cultures. In 2015, he was the main author of an industry report on practices of screenplay development for the Czech Film Fund. $\mathrm{He}$ is now working on a study of the digitalization of the Czech audiovisual industry and the impacts of the European Commission's Digital Single Market strategy.

Open Access This chapter is licensed under the terms of the Creative Commons Attribution 4.0 International License (http://creativecommons.org/licenses/by/4.0/), which permits use, sharing, adaptation, distribution and reproduction in any medium or format, as long as you give appropriate credit to the original author(s) and the source, provide a link to the Creative Commons license and indicate if changes were made.

The images or other third party material in this chapter are included in the chapter's Creative Commons license, unless indicated otherwise in a credit line to the material. If material is not included in the chapter's Creative Commons license and your intended use is not permitted by statutory regulation or exceeds the permitted use, you will need to obtain permission directly from the copyright holder.

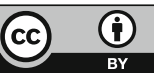

